\title{
Technical Efficiency of Melon Farming in Kulon Progo: A Stochastic Frontier Approach (SFA)
}

\author{
Ananti Yekti \\ Agricultural Post Graduate \\ Faculty of Agriculture \\ Gadjah Mada \\ University,And Magelang \\ AgricultureExtension \\ College, Indonesia
}

\author{
Dwidjono Hadi \\ Darwanto \\ Faculty of Agriculture \\ Gadjah Mada University, \\ Indonesia
}

\author{
Jamhari \\ Faculty of Agriculture \\ Gadjah Mada University, \\ Indonesia
}

\author{
Slamet Hartono \\ Faculty of Agriculture \\ Gadjah Mada University, \\ Indonesia
}

\begin{abstract}
Melon is a high-value horticulture commodity which is expected to increase farmer household's income in Kulon Progo Regency. The purpose of farming is not only to gain the highest resulting output but also the efficiency of input usage. Knowing the magnitude and distribution of technical efficiency has important implications for input allocations and farming managerial capability improvement. FRONTIER 4.1 software helps to estimate the stochastic production frontier and technical efficiency, as well as the ineffiency model as a one step process (simultaneously). The sample of this research were 100 melon farmers in Kulon Progo. Stochastic Frontier Approach using Cobb Douglas production function was applied in this research. The result reveals that 1) land use, quantity of seed, NPK fertilizer, organic fertilizer, pesticide, ricefield agroecosystem and wet season contributed significantly to melon production; 2) technical efficiency indeces ranged from 0.33 to 0.99 , with a mean of $0.64 ; 3$ ) farmer's age, level of education and large portion of loan for farming capital give significant influence to technical efficiency
\end{abstract}

\section{General Terms \\ Farm Management}

\section{Keywords}

Melon Farming, Technical Efficiency, Stochastic Frontier, Frontier 4.1.

\section{INTRODUCTION}

Agriculture gives $13.38 \%$ contribution to Indonesian GDP and providing jobs for $34.36 \%$ of the total national labor force [1]. As a part of agriculture, horticulture contributes in increasing smallholder farmers incomes, raises the demand for labor in rural areas, expanding employment opportunities and enhancing rural development. The balance of exports and imports of Indonesia in 2012 showed the value of exports of melon and watermelon were US\$521,390, while the value of imports reached US\$873,237 [2]. This condition reflects the demand for melon and watermelon in Indonesia can not be counterbalanced by domestic production, thus needing greater efforts to increase its production both in quantity and quality. Global market competition will encourage the integration of commodity markets, so one way to improve the competitiveness of commodities is by incerasing efficiency and productivity.

The purpose of production is not only to see how much output is produced but also the efficiency of the use of inputs. In terms of decision making, rational farmers would be willing to use more inputs as long as the added value generated by the additional input equals to or greater that the additional cost resulting from the additional input.

Melon has been cultivated in Kulon Progo Regency for the last few years and has become one of the important horticulture commodities. As a high-value horticultural commodity, it is expected to increase farmers household's income in Kulon Progo. Farmers cultivated melon in ricefield agroecosystem and coastal agroecosystem. Melon was planted both wet and dry season. Technical efficiency is one of the predictors in measuring the performance of production process [3]. Therefore, technical efficiency of melon farming was intended to measure the level of production that can be reached by farmers, given the finding of the research helps inefficient farmers in terms of productivity to have the ability to become more productive by referring to more efficient farmers.

The study measured technical efficiency of melon farmers in Kulon Progo Regency and identified the factors that determine technical inefficiency using stochastic frontier approach.

\section{LITERATURE REVIEW}

\subsection{Previous Study}

There have been many studies related to the efficiency using Stochastic Frontier approach (SFA). There were several studies in the field of agriculture that used SFA. Study by Rajendran (2014) conducted a research aimed to 1) measure technical efficiency of farming household that mainly grow food and vegetables in Nandu state; 2) identify determinants of technical inefficiency. The finding showed that the mean technical efficiency was 0.60 . The accessibility of infrastuctures, access to credit and level of education contributed positively to technical efficiency [4].

Subsequently, Nahraeni et al (2012) used stochastic frontier model to reveal many factors that affected technical efficiency of highland potato farming. Frontier 4.1 software was used to estimate production function parameters and inefficiency effect simultaneously. The result showed that production was highly responsive to land area, seed, and organic fertilizer. Land slope and contour aligned cultivation system increased efficiency significantly. Young farmers and higher education were highly responsive in applying new technology. The average level of technical efficiency was 0.84 [5] 
Suharyanto et al (2013) examined technical efficiency of rice Integrated Crop Management (ICM) in Bali Province using frontier production function that estimated with MLE method, with focused to measured 1) the level of technical efficiency in rice with ICM approach and 2) to analyze factors influencing its technical efficiency. Estimation source of technical inefficiency applies linear regression model estimated simultaneouly with frontier production function. Level of technical efficiency reached by farmer varies between $0.71-0.99$ with average of 0.88 . Land use, quantity of seed, active nitrogen, organic fertilizer, pesticide and wet season have positive impact on the rice yield. The factors that significantly influencing to technical inefficiency was farmer's ages, education level, farm experiences and number of parcel of land ownership [6].

\subsection{Measurement of Technical Efficiency}

Technical efficiency is one of the indicators in measuring the performance of production process. Measuring efficiency is important because it is the first step in the process leading to substantial resource saving. Resource saving has an important implication both in policy formulation and farm management [7]. Efficiency is defined as an effort to utilize minimum input in order to gain maximum output [8]. Technical efficiency is a combination of capacity and ability of economic units to produce the maximum output from a number of input and technology. Technical efficiency measures the level of production achieved by using a certain level of inputs. A farmer is technically said to be more efficient than others when the utilization of the same type and number of inputs obtained higher physical output [9]. The measurement of technical efficiency was first purposed by Farel (1957), which is stated as the ability of a firm to obtain maximum output from a given set of input [10].

\subsection{Stochastic Frontier Approach}

There are two methods available in measuring efficiency by estimating frontier production function as follows: 1) parametric approach by using Stochastic Frontier Analysis (SFA) and 2) non parametric approach by using Data Envelopment Analysis (DEA). Stochastic frontier analysis is a parametric technique that uses standard production function methodology. Stochastic frontier method can be used directly to test the hypothesis associated with the production function model [11]. A number of different functional forms are used in the literature to model productin function, such: CobbDouglass, Translog and CES. This study uses the CobbDouglass production function, is mathematically written [12]:

$$
\begin{aligned}
& \mathrm{Y}=\alpha \mathrm{X}_{1}^{\mathrm{b} 1} \mathrm{X}_{2}^{\mathrm{b} 2} \ldots \mathrm{X}_{\mathrm{n}}^{\mathrm{bn}} \mathrm{e}^{\mathrm{u}} \\
& \text { Where: } \\
& \mathrm{Y}=\text { dependent variable } \\
& \mathrm{X}=\text { independent variable } \\
& \alpha=\text { intercept } \\
& \mathrm{b}=\text { parameter for each input } \mathrm{X}_{\mathrm{i}} \\
& \mathrm{u}=\text { disturbance term } \\
& \mathrm{e}=\text { natural logaritma }
\end{aligned}
$$

Frontier production function illustrates the potential production that can be obtained from a combination of input variations in the level of technology and specific knowledge [13]. Frontier production model allows to infer or estimate the relative efficiency of a particular farm is obtained from the relationship between production and production potential that can be achieved [14].

Stochastic frontier analysis (SFA) is an alternative method for estimating the frontier function and the efficiency of production. The stochastic frontier production function was initially developed by Aigner, Lovell, and Schmidt (1977) and Meeusen and van den Broeck (1977) [15]. Stochastic frontier production function postulates the existence of production technical inefficiency at the firm involved in producing a particular output [16]. The specification allows a non-negative random component in the error term to generate a measure of technical inefficiency, or the actual ratio to expected maximum output, with the given inputs and the existing technology [17]. Stochastic production frontiers indicate the maximum expected output for a given set of inputs. They are derived from the production theory and are based on the assumption that output is a function of the level of inputs and the efficiency of the producer in using those inputs [18]

Estimation of the frontier function requires one to specify a functional form for the production function. According to [19] stochastic frontier production function in a general function form generally specified as:

$$
\ln \mathrm{q}_{\mathrm{i}}=x_{i}^{\prime} \beta+\mathrm{v}_{\mathrm{i}}-\mathrm{u}_{\mathrm{i}}
$$

In Cobb-Douglass production function, stochastic frontier function for the i-th firm take the form:

$$
\begin{aligned}
& \operatorname{Ln} q_{i}=\beta_{o}+\beta_{1} \ln x_{i}+v_{i}-u_{i} \\
& q_{i}=\exp \left(\beta_{o}+\beta_{1} \ln x_{i}+v_{i}-u_{i}\right)
\end{aligned}
$$

Where $q_{i}$ is the output of the $i$-th firm; $x_{i}$ represents $K \times 1$ vector containing the natural logarithms of input; $\beta$ is a vector of unknown parameters; $v_{i}$ is random variables which is assumed to be iid. $\mathrm{N}\left(0, \sigma_{\mathrm{v}}{ }^{2}\right)$ and independent of the $\mathrm{u}_{\mathrm{i}}$ which is a non-negative random variables, accounting for technical inefficiency in production, and assumed to be iid. $\mathrm{N}\left(0, \sigma_{\mathrm{u}}{ }^{2}\right)$ distribution. $v_{i}$ is a symmetric random error to account for statistical noise while $u_{i}$ is a non-negative random variable associated with technical efficiency. The general form of the value of technical efficiency achieved by the i-th observation at all time $\mathrm{t}$, which is used in this study refers to Coelli et al [20] as follows :

$$
\begin{aligned}
\mathrm{TE} & =\frac{q_{i}}{\exp \left(x_{i}^{\prime} \beta+v_{i}\right)} \\
& =\frac{\exp \left(x_{i}^{\prime} \beta+v_{i}-u_{i}\right)}{\exp \left(x_{i}^{\prime} \beta+v_{i}\right)} \\
& =\exp \left(-\mathrm{u}_{\mathrm{i}}\right)
\end{aligned}
$$

The model can estimate the parameters of stochasik production frontier and inefficiency models simultaneously. To determine the value of the parameter of technical inefficiency effects $\left(\mathrm{u}_{\mathrm{i}}\right)$ using equation 5 .

$\mathrm{u}_{\mathrm{i}}=\delta_{0}+\delta_{1} \mathrm{Z}_{1}+\delta_{2} \mathrm{Z}_{2}+\ldots+\delta_{\mathrm{n}} \mathrm{Z}_{\mathrm{n}}$

Where:

$\mathrm{u}_{\mathrm{i}}=$ technical efficincy effect

$\delta=$ vector of parameters

$\mathrm{Z}=$ vector of firm-specific variables which may influence the firm's efficiency

$\beta$ and $\delta$ coeffisients are unknown parameters to be estimated, together with the variance parameters which are expredded in term of:

$\sigma^{2}=\sigma_{v}^{2}+\sigma_{u}^{2} \quad$ and $\quad \gamma=\frac{\sigma_{u}^{2}}{\sigma^{2}}$

where $\sigma^{2}$ is the total variance of the error term. $\gamma$ parameter value is the contribution of technical efficiency in the residual error $(\varepsilon)$ whose value ranges between zero and one. $\gamma$ parameter values are close to zero indicates that the deviation from the frontier increasingly lead to the residual effect 
(error). Maximum likelihood methods are used in estimating the unkonown parameters.

\subsection{Frontier Analysis}

There are several software packages generally available for estimating stochastic production frontiers, such as: STATA, LIMDEP and FRONTIER. FRONTIER is a single purpose package specifically designed for the estimation of stochastic production frontiers and technical efficiency. FRONTIER estimates an inefficiency model as a one-step process. FRONTIER 4.1 is commonly used for estimating stochastic production frontiers. Single-stage procedur has more advantage than the two-stage approach in that includes frontier and technical inefficiency model together and estimate simultaneously [21].

\section{RESEARCH METHODOLOGY}

\subsection{Data Collection}

This research was conducted in Kulon Progo Regency. The selection of farming location was carried out purposively such as in the Galur and Lendah Districts by considering that these districts were the production centre of melon production in Kulon Progo.

Data was collected by interviewing 50 farmers in District Galur (represented coastal agroecosytem) and 50 farmers in District Lendah (represented ricefall agroecosystem) which had planted melon in 2013. From 100 respondents, 92 respondents planted melon during dry season and 77 respondents during wet season, adding up to 169 farming data.

\subsection{Data Processing}

Stochastic Frontier approach was applied in measuring efficiency in this study. The variables consist of two sets of data: 1) variables on melon output and input used on a farm basis, and 2) technical inefficiency determinant variables such social-economic charateristic.

The parameters of the stochastic frontier production function model were estimated by method of Maximum Likelihood, using Frontier 4.1 software package written by Coellie at al. (1996) [22]. Cobb-Douglass stochastic frontier production model are estimated by the method of maximum likelihood, shown in equation 7 .

$$
\begin{aligned}
\ln Y= & \beta_{0}+\beta_{1} \ln X_{1}+\beta_{2} \ln X_{2}+\beta_{3} \ln X_{3}+\beta_{4} \ln X_{4}+\beta_{5} \\
& \ln X_{5}+\beta_{6} \ln X_{6}+\beta_{7} \ln X_{7}+\beta_{8} \ln X_{8}+\beta_{9} \ln D_{9}+ \\
& \beta_{10} \ln D_{10}+\left(v_{i}-u_{i}\right) \\
\text { where: } & \\
Y_{i}= & \text { production }(\mathrm{kg}) \\
X_{1}= & \text { land area }\left(\mathrm{m}^{2}\right) \\
X_{2}= & \text { seed }(\mathrm{gr}) \\
X_{3}= & \text { ZA fertilizer }(\mathrm{kg}) \\
X_{4}= & \text { SP-36 fertilizer }(\mathrm{kg}) \\
X_{5}= & \text { NPK fertilizer }(\mathrm{kg}) \\
X_{6}= & \text { organic fertilizer }(\mathrm{kg}) \\
X_{7}= & \text { pesticide (kg) } \\
X_{8}= & \text { labour (Man day) } \\
D_{9}= & \text { agroecosystem (1=ricefield } ; 0=\text { coastal) } \\
D_{10}= & \text { growing season (1=dry season; } 0=\text { wet } \\
& \text { season) }
\end{aligned}
$$

Simultaneously, the non-negative random variable, $\mathrm{u}_{\mathrm{i}}$, for estimating the technical inefficiency of farming is defined in equation 8 .

$$
u_{i}=\delta_{0}+\delta_{1} \ln Z_{1}+\delta_{2} \ln Z_{2}+\delta_{3} \ln Z_{3}+\delta_{4} D_{4}
$$

where:

$u \quad=$ Technical ineffeciency effect

$\delta \quad=$ Coefficient parameter

$Z_{1} \quad=$ Age (years)

$Z_{2} \quad=$ Formal education (years)

$Z_{3} \quad=$ Farming experience (years)

$D_{4} \quad=$ Dummy portion of capital source $(1=\geq 50 \%$ private capital; $0=<50 \%$ private capital)

\section{RESULT AND DISCUSSION}

The result for the Cobb-Douglass production function and the technical inefficiency determinats from the stochastic frontier were analyzed simultaneously, but they are presented separately in Table 1 and Table 2.

Table 1. Maximum Likelihood Estimates for parameters of Cobb-Douglass stochastic production frontier function

\begin{tabular}{|l|r|r|r|}
\hline \multicolumn{1}{|c|}{ Variables } & Coefficient & $\begin{array}{c}\text { Standard } \\
\text { Error }\end{array}$ & \multicolumn{1}{c|}{ t-ratio } \\
\hline Constant & 2.5824 & 0.3025 & $8.5349^{* * *}$ \\
\hline Land area & 0.5767 & 0.0703 & $8.2083^{* * *}$ \\
\hline Seed & 0.2298 & 0.0578 & $3.9753^{* * *}$ \\
\hline ZA fertilizer & 0.0302 & 0.0448 & 0.6732 \\
\hline SP-36 fertilizer & -0.0410 & 0.0377 & -0.0891 \\
\hline NPK fertilizer & 0.0637 & 0.0255 & $2.5018^{* * *}$ \\
\hline Organic fertilizer & 0.0756 & 0.0262 & $2.8762^{* * *}$ \\
\hline Pesticide & 0.0371 & 0.0107 & $3.4639^{* * *}$ \\
\hline Labour & -0.0358 & 0.0693 & -0.5158 \\
\hline $\begin{array}{l}\text { Dummy } \\
\text { agroecosystem }\end{array}$ & 0.1804 & 0.0663 & $2.7174^{* * *}$ \\
\hline $\begin{array}{l}\text { Dummy growing } \\
\text { season }\end{array}$ & 0.1025 & 0.0256 & $4.0036^{* * *}$ \\
\hline Sigma-squared $\left(\sigma^{2}\right)$ & 0.0757 & 0.0036 & $21.1939^{* * *}$ \\
\hline Gamma $(\gamma)$ & 0.9999 & 0.0001 & $8852.37^{* * *}$ \\
\hline
\end{tabular}

Source: processed data, 2015

Note: ${ }^{* * * * * *}$, indicate significant at $1 \%, 5 \%$ and $10 \%$ levels, respectively

As shown in Table 1, all parameters estimated are statistically significant, except for ZA fertilizer, SP-36 fertilizer and labour. Land area, seed, NPK fertilizer, organic fertilizer and pesticide had a positive and significant coefficient. This study used the Cobb-Douglass production function, so the estimated coefficients shown of input elasticity directly. The highest elasticity input was land area. It indicated that melon production was very responsive to the land area increasing. Additional of land area (ceteris paribus) of $1 \%$ would increase the production of melon by $0.57 \%$. It was also applied to other production factors. Additional of $1 \%$ of seed, NPK fertilizer, organic fertilizer and pesticide, would increase melon production by $0.23 \%, 0.6 \%, 0.08 \%$ and $0.04 \%$.

Agroecosystem and the growing season also had a positive and significant coefficient. It means ricefield agroecosystem provided higher production then coastal agroecosytem, as well as farming during wet season gave the higher production then during dry season. The sign of coefficients of all variables in production function were positive except phosphat fertilizer and labours which were negative.

$\sigma^{2}$ and $\gamma$ parameters present result on the behavior of the error term outlined in the inefiiciency model. Estimation for the variance parameters $\sigma^{2}$ and $\gamma$ are statistically significant from 
zero at $1 \%$ level, respectively. This means that inefficiency effects mainly originate from the measurement term $\sigma_{v}^{2}$, not from $\sigma_{u}^{2}$. It indicates the presence of technical inefficiency in the melon farming activities. It should be noted that $99,9 \%$ of the variation in melon production is due to technical inefficiency and only $0,1 \%$ is due to the random error.

Table 2. Determinants of Technical Inefficiency

\begin{tabular}{|l|r|r|r|}
\hline \multicolumn{1}{|c|}{ Variables } & Coefficient & $\begin{array}{c}\text { Standard } \\
\text { Error }\end{array}$ & \multicolumn{1}{c|}{ t-ratio } \\
\hline Constant & -0.1508 & 0.4218 & -0.3576 \\
\hline Age & 0.2407 & 0.1051 & $2.2908^{* *}$ \\
\hline Formal education & -0.1424 & 0.0639 & $-2.2302^{* *}$ \\
\hline Farm experience & 0.0681 & 0.0421 & 1.6176 \\
\hline $\begin{array}{l}\text { Dummy portion } \\
\text { of capital source }\end{array}$ & -0.1252 & 0.0592 & $-2.1162^{* *}$ \\
\hline
\end{tabular}

Source: processed data, 2015

Note: ${ }^{* * * * * *}$, indicate significant at $1 \%, 5 \%$ and $10 \%$ levels, respectively

Table 2 shows the coefficient of explanatory variables in the inefficiency model. They are significant at various level. The negative sign of parameters means improving technical inefficiency, vice versa. Age had postive and significant effect in technical inefficiency. This implied that older farmers were more inefficient then the younger ones. It is reasonable since labour productivity decrease with age, yonger farmer tend to be more productive than their older counterpart. It can imply that younger farmers may comparatively more educated than the older. Coofficient of farmer education was negative and statistically significant at $5 \%$. This means farmer with higher education would be more efficient. It shows education is one of important factors that sharpens managerial capabilities of farmer.

Portion of capital source also had significantly negative impact. It means using more capital sources from loan would be more efficient technically and may lead to higher levels of output. Availability of capital enable farmers to purchase inputs on time. Melon farming requires large capital. Most farmers get the larger portion of their cost farming from loan, due to the limitations of self-owned capital. Only the estimate coefficient on farmer experience is not statiscally significant.

Distribution of technical efficiency indices had important implications for improving farm managerial capabilities through the development of agricultural extension [23]. Technical efficiency indeces of melon farming is classified into seven groups, as presented in Figure 1.

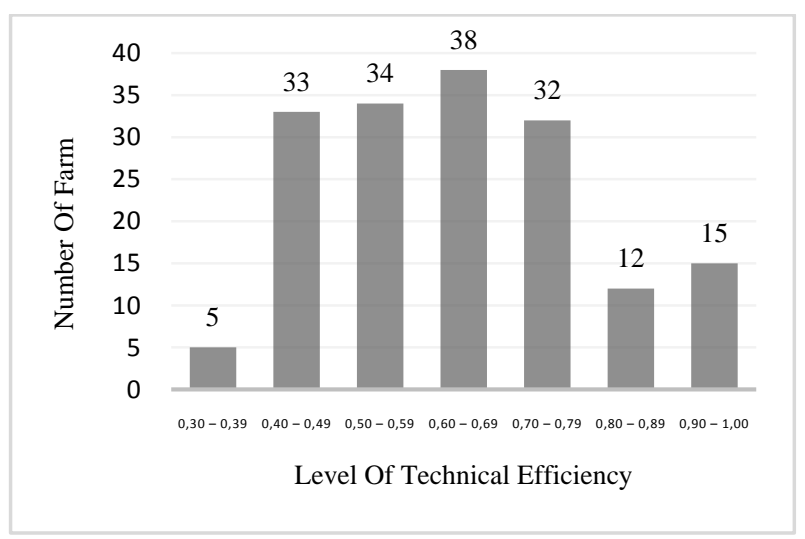

Figure 1. Distribution of Technical Efficiency Indices
The study shown that technical efficiency indices varied from 0,3384 to 0.9998 , with mean at 0.6410 . There was a wide gap between the highest and the lowest technical efficiency index. More then half of farmers (56.21\%) have technical efficiency index below average. It illustrates that the majority of farmer in the study area were not efficient technically. Result of the study indicated a considerable room for improvement in melon production with the given resource base and available technology. The mean of technical efficiency index indicates if the farmer in study area could achieve the technical efficieny level of his/her most counterpart, he/she could increase output by about $35 \%$ (which calculated 1$(0.64 / 0.99) \times 100 \%)$, while the most inefficient farmer could increas output by about $66 \%$ (calculated $1-(0.34 / 0.99) \times 100 \%)$.

The magnitude and distribution of technical efficiency indices have important implications for improving farm managerial capabilities through the development of extention service strategies. Efforts to improve the technical efficiency can be done by applying the skills and techniques of cultivation, as was done by the most efficient farmers, i.e farmers who were able to achieve the highest tecnical efficiency of 0.9998 . The efficient farms are likely to generate higher incomes and thus stan a better chance of surviving and prospering [24]. Improvement in resource use efficiency can contribute remarkably to increase production, then revenue at the farm level.

\section{CONCLUSIONS}

This study reveals that melon production and technical efficiency has potency to be increased in Kulon Progo district. Melon production increasment in Kulon Progo is achieveable through the utilization of the following production factors, namely: land area, seed, NPK fertilizer, organic fertilizer and pesticide. Planting in rice fields agroecosytem and during dry season are also an important alternative to applied.

Farmers who have not been technically efficient, can adopt the cultivation techniques and how to manage the farm of the farmer with a high level of technical efficiency. The enhancement of technical efficiency can be achieved by improving the farmers' level of education, conducting farm business at a younger age and the usage of capital sources in the form of loan for their farm total cost.

\section{ACKNOWLEDGMENT}

I would like to thank to Ministry of Agriculture, Republik Indonesia, for the doctoral program scholarship in Gadjah Mada University.

\section{REFERENCES}

[1] Badan Pusat Statistik. 2014. Berita Resmi Statistik Indonesia. Jakarta

[2] Direktorat Jendral Hortikultura. 2014. Basis Data Ekspor-Import Komoditi Pertanian. Kementrian Pertanian Republik Indonesia.

[3] Banani, Ade. Muslich Mustadjab. Djoko Koestiono, Syafrial. 2013. Production Management and Technical Efficiency of Red Onion Farming in Brebes Regency. Journal of Basic and Applied Scientific Research. 3(3), 85-90.

[4] Rajendran, Srinivasulu. 2014. Technical Efficiency of Fruits and Vegetables Producers in Tamil Nadu, India: A Stochastic Fronter Approach. Asian Jounal of Agriculture and Development, Vol. 11 No.1, 77-93. 
[5] Nahraeni, Wini. S. Hartoyo. Y Syaukat. Kuntjoro. 2012. Pengaruh Kemiringa Lahan Dan Sistem Konservasi terhadap Efisiensi Usahatani Kentang Dataran Tinggi. Jurnal Pertanian. Vol. 3 No. 1, 1-12.

[6] Suharyanto, Mulyo, J.H., Darwanto, D.H., Widodo, S. 2013. Analisis Efisiensi Teknis Pengelolaan Tanaman Terpadu (PTT) Padi Sawah Di Provinsi Bali. Jurnal SEPA Vol. 9. No.2, 219-230

[7] Bravo-Ureta, B. E and Rieger, L. 1991. Dairy Farm Efficiency Management Using Stochastic Frontiers and Neoclassical Duality. American Journal of Agricultural Economics, 73(2), 421-428.

[8] Soekartawi, 2002. Analisis Usahatani. Jakarta : UI Press

[9] Lau, L. J., and P. A. Yotopoulos, 1971. A Test for Relative Efficiency and Aplication to Indian Agriculture. American Journal of Agricultural Economics, 61(3), 94109

[10] Taraka, Kallika. Mad Nasir Shamsudin. Ismail Abd, Latif. Shaufique bin Ahmad Sidique. 2012. Estimation of Technical Efficiency for Rice Farms in Central Thailand Using Stochastic Frontier Approach. Asian Journal of Agriculture and Fevelopment, Vo. 9. No.2, 1-11.

[11] Dijk, M. van, and A. Szirmai, 2006. Technical Efficiency and Embodied Technical Change in the Indonesian Pulp and Paper Industry', Journal of International Development, 18, 163-178.

[12] Beattie, Bruce dan C. Robert Taylor. 1994. Ekonomi Produksi. Terjemahan Soeratno Josohardjono dan Gunawan Sumodiningrat. Gadjah Mada Universty Press. Yogyakarta.

[13] Doll, J.P and Orazem, F,. 1978. Production Economics: Theory with Application. Grind Inc. Columbus. Ohio

[14] Green, W. H. 1993. The Economic Approach to Effciency Analysy. In Fried H.O., C.A.K. Lovel, and P. Schmidt (eds). The Measurment of Productivity Efficiency: Technique and Applications. Oxford University Press. New York.

[15] Saptana. Arief Daryanto. Heny, K. Daryanto. Kuntjoro. 2010. Analisis Efisiensi Teknis Produksi Usahatani
Cabai Merah dan Perilaku Petani dalam Menghadapi Risiko. Jurnal Agro Ekonomi. Volume 28 No.2, 153-188.

[16] Battese, G.E. and Coelli, T.J., 1995. A Model for Technical Inefficiency Effects in a Stochastic Frontier Production Function for Panel Data. Empirical Economics. 20, 325-332.

[17] Kompas, Tom. 2001. Cacth Efficiency and Management: a Stochastic Production Analysis of the Australian Northern Prawn Fishery. International and Development Economics Working Paper 1-8. The Australian National University.

[18] Pascoe, S., Kirkley, J.E., Greboval, D., Morrison-Paul, C.J. 2003. Measuring and assessing capacity in fisheries. 2. Issues and methods. FAO Fisheries Technical Paper. No. 433/2. Rome, FAO. 130p

[19] Aigner, D.J., C.A.K. Lovell and P. Schmidt. 1977. Formulation and Estimation of Stochastic Frontier Production Function Models. Journal of Econometrics, 6(1), 21-37.

[20] Coelli, T. J., D. S. P. Rao and G.E. Battese. 2005. An Introduction to Efficiency and Productivity Analysis $2^{\text {nd }}$, Springer Science + Business Media, Inc.

[21] Battese, G.E., and T.J. Coelli. 1995. A Model for Technical Inefficiency Effect in Stochastic Frontier Production Function for Panel Data. Empirical Economics 20 (2), 325-332.

[22] Coelli, T. J. 1996. A Guide to FRONTIER Version 4.1 A Computer Program for Stochastic Frontier Production and Cost Function Estimation, CEPA Working Paper 96/07, Departemen of Econometrics, University of New England, Armidale, NSW, 2351, Australia.

[23] Sumaryanto, 2001. Estimasi Tingkat Efisiensi Usahatani Padi Dengan Fungsi Produksi Frontir Stokastik. Jurnal Agro Ekonomi. 19 (1), 65-84.

[24] Rahman, K.M.M, M.I.A. Mia and M.K.J. Bhuyan. 2012 A Stochastic Frontier Approach to Model Technical Efficiency of Rice Farmers in Bangladesh: An Empirical Analysis. The Agriculturists 10(2), 9-19. 